\title{
Short-term growth and biomechanical responses of the temperate seagrass Cymodocea nodosa to $\mathrm{CO}_{2}$ enrichment
}

\author{
Carmen B. de los Santos ${ }^{1, *}$, Jasmin A. Godbold ${ }^{2,3}$, Martin Solan ${ }^{2}$ \\ ${ }^{1}$ Centre of Marine Sciences (CCMAR), University of Algarve - Campus de Gambelas, 8005-139 Faro, Portugal \\ ${ }^{2}$ Ocean and Earth Science, National Oceanography Centre Southampton, University of Southampton, Waterfront campus, \\ European Way, Southampton, SO14 3ZH, UK \\ ${ }^{3}$ Biological Sciences, University of Southampton, Life Sciences Building, Highfield campus, Southampton, SO17 1BJ, UK
}

\begin{abstract}
Seagrasses are often regarded as climate change 'winners' because they exhibit higher rates of photosynthesis, carbon fixation and growth when exposed to increasing levels of ocean acidification. However, questions remain whether such growth enhancement compromises the biomechanical properties of the plants, altering their vulnerability to structural damage and leaf loss. Here, we investigated the short-term ( $6 \mathrm{wk}$ ) effects of decreasing $\mathrm{pH}$ by $\mathrm{CO}_{2}$ enrichment on the growth, morphology and leaf-breaking force of the temperate seagrass Cymodocea nodosa. We found that the plant biomass balance under levels of acidification representative of short-term climate change projections ( $\mathrm{pH}$ 8.04) was positive and led to an increase in leaf abundance in the shoots. However, we also found that plant biomass balance was negative under levels of acidification experienced presently ( $\mathrm{pH}$ 8.29) and those projected over the long-term ( $\mathrm{pH} 7.82$ ). Leaf morphology (mean leaf length, thickness and width) was invariant across our imposed acidification gradient, although leaves were slightly stronger under $\left[\mathrm{CO}_{2}\right]$ representative of short-term climate change. Taken together, these findings indicate that a subtle increase in growth and mechanical resistance of $C$. nodosa is likely to occur following short- to medium-term changes in ocean chemistry, but that these positive effects are unlikely to be maintained over the longer term. Our study emphasises the need to account for the interdependencies between environmental conditions and variations in multiple aspects of the structure and functioning of seagrass communities when considering the likely consequences of climate change.
\end{abstract}

KEY WORDS: Biomechanics $\cdot$ Breaking force $\cdot$ Structural change $\cdot$ Ocean acidification $\cdot$ Carbon dioxide $\cdot$ Response traits $\cdot$ Growth $\cdot$ Cymodocea nodosa

\section{INTRODUCTION}

Ocean $\mathrm{pH}$ levels are predicted to decrease by approximately 0.4 units by 2100 due to increasing anthropogenic $\mathrm{CO}_{2}$ partial pressure in the seawater (Stocker et al. 2013), and there is a clear consensus that ocean acidification will form a major challenge for marine biota and ecosystems (Fabry et al. 2008). However, experimental manipulations of ocean acidification reveal that species responses take time to

${ }^{*}$ Corresponding author: carmen.bdelossantos@gmail.com develop and to be expressed (Form \& Riebesell 2012, Godbold \& Solan 2013) and that there are significant variations in the vulnerability of species, ranging from negative responses (e.g. growth, calcification, reproduction and survival), through resistance, to positive effects (growth, photosynthesis) in some noncalcifying species (Kroeker et al. 2010, 2013). For marine macrophytes, the increased availability of bicarbonate $\left(\mathrm{HCO}_{3}{ }^{-}\right)$and dissolved inorganic carbon commonly enhances primary productivity and

(1) The authors, Universidade do Algarve and University of Southampton 2017. Open Access under Creative Commons by Attribution Licence. Use, distribution and reproduction are unrestricted. Authors and original publication must be credited.

Publisher: Inter-Research · www.int-res.com 
growth (reviewed by Koch et al. 2013), providing that there is sufficient light and nutrients. Under these circumstances, seagrass communities can modify the carbonate chemistry of the entire local environment and, in turn, influence species-environment interactions. For instance, seagrasses indirectly protect associated invertebrate communities from exposure to acidification by buffering changes in ocean chemistry, as reported for tropical seagrass communities (Unsworth et al. 2012) and Mediterranean Posidonia oceanica meadows (Garrard et al. 2014, Hendriks et al. 2014).

Growth enhancement by ocean acidification may involve associated responses in the organisms, such as the alteration of mechanical properties, although this remains a less prominent area of research. Mechanical resistance is an important feature in protecting marine plants from biotic (herbivory, e.g. Vergés et al. 2007) and abiotic forcing (drag, e.g. de los Santos et al. 2016a). The force needed to abscise the leaf at the ligule, the joint between the leaf sheath and blade in most seagrass species, is an important leaf trait that retains the structural integrity of the plant. Leaf shedding is ultimately controlled by the balance of the leaf-breaking force at the abscission area and an external environmental force, such as hydrodynamic forces associated with the action of waves and currents, especially during storms. Yet, studies on the effects of ocean acidification on the mechanical properties of marine flora are scarce, despite expectations that the severity and frequency of storms will increase with climate change. The few studies that have been conducted have predominantly focussed on calcified algae (e.g. Ragazzola et al. 2012, Newcomb et al. 2015), but the extent to which the biomechanics of seagrasses respond to ocean acidification has not been fully investigated.

There are reasons, however, to expect changes in the mechanical properties of seagrass leaves in acidified waters. First, seagrasses show considerable phenotypic plasticity in the mechanical traits of leaves, allowing adjustments to their physical environment and nutrient or light supply (Kopp 1999, La Nafie et al. 2012, 2013, de los Santos et al. 2013, 2016a). Secondly, high levels of carbon fixation associated with elevated $\left[\mathrm{CO}_{2}\right]$ lead to both an increased $\mathrm{C}: \mathrm{N}$ ratio and an increased concentration of non-structural carbohydrates in seagrasses that have to be relocated by the plant (Jiang et al. 2010). Similarly, at elevated $\left[\mathrm{CO}_{2}\right]$, excess carbon may be available, which may allow individual plants to invest in structural carbonbased components allocated to the cell wall constituting the fibre bundles, which are a major sink for car- bohydrates. The allocation of supporting tissues in the leaf contributes substantially to its material strength (de los Santos et al. 2016a), which determines, along with the leaf cross-sectional area, the leaf-breaking force (i.e. the maximum capacity of a leaf to withstand a physical force), a trait reflecting the tolerance of plants against mechanical damage (Niklas 1992). Hence, under elevated $\left[\mathrm{CO}_{2}\right]$, seagrasses may experience structural reinforcement of the leaves that is associated with growth enhancement and of a magnitude sufficient to increase their tolerance to physical forces. Thus, physiological and morphological acclimation of seagrasses to elevated $\left[\mathrm{CO}_{2}\right]$ has the potential to alter plant physical performance and/or to modify entry to the food web through herbivory and/or decomposition (Read \& Stokes 2006).

Here, we assessed the short-term response (6 wk) in growth, leaf morphology, and leaf-breaking force of the seagrass Cymodocea nodosa (Ucria) Ascherson to elevated $\left[\mathrm{CO}_{2}\right]$. We also examined the correlation between leaf growth and breaking force responses to investigate whether growth enhancement compromises plant biomechanical properties.

\section{MATERIALS AND METHODS}

\section{Test species and plant material}

Cymodocea nodosa is a small, fast-growing species with low storage capacity and high turnover time (Duarte 1991). It also exhibits high intra-specific variability in its leaf morphology and mechanical traits (de los Santos et al. 2013) as well as in its physiology (e.g. Olivé et al. 2013). In addition, C. nodosa shows rapid growth responses to a wide range of environmental drivers within a time frame of several weeks (e.g. nutrients, Pérez et al. 1991; light, Malta et al. 2006; salinity, Pagès et al. 2010), including $\mathrm{CO}_{2}$-induced pH reduction (Invers et al. 2001, Tomas et al. 2015).

C. nodosa plants were collected by hand from a continuous intertidal meadow in the inner Cádiz Bay (southern Spain, $36.48^{\circ} \mathrm{N}, 6.26^{\circ} \mathrm{W}$ ) on 15 October 2012. Cádiz Bay is a sheltered shallow tidal lagoon (3 m mean water depth) dominated by unidirectional flows, and is abundantly covered by benthic macrophytes (de los Santos et al. 2013). Mean annual water temperature and salinity in the bay are $19.3^{\circ} \mathrm{C}$ (range $13.7-24.4^{\circ} \mathrm{C}$ ) and 34 , respectively (Vergara et al. 2012). The light regime in Cádiz Bay varies greatly with the low/high tide, wind regime and other environmental factors (Morris et al. 2009), but a typical 
range of irradiance would be 150 to $>1500 \mu \mathrm{mol}$ photons $\mathrm{m}^{-2} \mathrm{~s}^{-1}$ in the upper subtidal areas during low tide in summer (Malta et al. 2006).

Plants were rinsed with seawater at the collection site, carefully packed in wet and dark conditions in a cool box and transported to the Biodiversity and Ecosystem Futures Facility at the National Oceanographic Centre Southampton, University of Southampton, UK. Within $<36 \mathrm{~h}$ of collection, plants were submersed in aerated seawater (temperature $19^{\circ} \mathrm{C}$, salinity 34) for a $10 \mathrm{~d}$ acclimation period under saturating light conditions $\left(380 \mu \mathrm{mol}\right.$ quanta $\mathrm{m}^{-2} \mathrm{~s}^{-1}$; Olivé et al. 2013), with a photoperiod of $18 \mathrm{~h}$ of light and $6 \mathrm{~h}$ of darkness.

\section{Experimental set-up}

The plants of $C$. nodosa used for the experiment consisted of a single lateral shoot with a bundle of leaves attached to a rhizome portion including 2 nodes, an internode of ca. $2-3 \mathrm{~cm}$ and corresponding roots. After tagging and measuring the initial architectural traits (described below) of each plant, they were transferred in pairs to thin-walled $(5 \mathrm{~mm})$ transparent Perspex aquaria (internal dimensions, length $\times$ width $\times$ height $=10 \times 10 \times 33 \mathrm{~cm}$ ) filled with $10 \mathrm{~cm}$ of sediment overlain by $\sim 20 \mathrm{~cm}$ of seawater. Sediment was collected from an area that hosts significant populations of seagrass (Zostera marina, Calshot intertidal flat, $\left.50^{\circ} 48^{\prime} \mathrm{N}, 1^{\circ} 19^{\prime} \mathrm{W}, \mathrm{UK}\right)$, sieved (500 $\mu \mathrm{m}$ mesh) in a filtered seawater bath to remove macrofauna and mixed with commercially sourced natural gravel (granules, size class 2-4 mm) in a 3:2 volume ratio. Aquaria were filled with 21 of natural seawater (UV sterilised, $10 \mu \mathrm{m}$ filtered, salinity 34) and randomly placed within a water bath maintained at 19.6 $\pm 0.2^{\circ} \mathrm{C}$. No nutrients were added. Plants were acclimated to laboratory conditions for an additional $5 \mathrm{~d}$ before the start of the experiment. During this acclimation period, no plant dieback was observed.

Aquaria were individually, directly and continuously bubbled with ambient air or $\mathrm{CO}_{2}$-enriched air during the entire experiment, using a custom built $\mathrm{CO}_{2}$-air mixing system (Godbold \& Solan 2013) to represent atmospheric $\left[\mathrm{CO}_{2}\right]$ indicative of present day (380 ppm, 'present day') versus projected (750 and $1000 \mathrm{ppm}$, 'short-term projected' and 'long-term projected', respectively) conditions (Stocker et al. 2013). For each $\left[\mathrm{CO}_{2}\right]$ treatment, air and $\mathrm{CO}_{2}(\mathrm{BOC}$, $\mathrm{CP}$ Grade $\mathrm{CO}_{2} 99.995 \%$ ) were mixed in an airtight and pressure-resistant vessel before being fed through a flow-controller into a Licor LI-840A in- frared gas analyser and distributed to the aquaria. Aquaria were continuously bubbled and sealed with a transparent Perspex lid (1 $\mathrm{mm}$ thick) following established methods and best practice guidelines (Riebesell et al. 2010, Godbold \& Solan 2013). Each lid was cleaned of evaporated salts twice a day to minimise restriction of light. Each $\left[\mathrm{CO}_{2}\right]$ treatment was replicated 10 times. In addition, 3 aquaria were maintained without plants under the same experimental conditions to monitor seawater $\mathrm{pH}$ without the modifying effects of seagrass productivity.

Aquaria were illuminated with a modular light source (Mazarra LED Lighting System, P-series) consisting of 16 modules $(230 \times 230 \mathrm{~mm})$, each housing 16 LEDs: colour temperature/wavelength/LED model: $4 \times$ cool white/7000-8000 K/Cree Xlamp XM-L; 4× blue/460-490 nm/Philips Luxeon Rebel; $4 \times$ royal blue/440-460 nm/Philips Luxeon Rebel ${ }_{i} 1 \times$ super actinic/400-410 nm/Epileds Dual-Core; $1 \times$ super actinic/410-420 nm/Epileds Dual-Core; and $2 \times$ warm white/3000 K/Cree Xlamp XP-G. This light arrangement was designed to deliver the light at an intensity of photosynthetically active radiation sufficient to saturate photosynthesis, with a spectrum similar to the spectral distribution of sunlight. The photoperiod and down-welling plane surface irradiance (measured at the water surface with a Li-Cor LI190R light meter connected to a logger unit LI-250A) were set in a dawn-daylight-dusk-night cycle: dawn lasted for $0.5 \mathrm{~h}$ with a gradual increase in irradiance from $21.3 \pm 3.2$ to $383.3 \pm 33.6 \mu \mathrm{mol}$ quanta $\mathrm{m}^{-2} \mathrm{~s}^{-1}$, and then remained constant for a further $17 \mathrm{~h}$; dusk also lasted for $0.5 \mathrm{~h}$, gradually decreasing light to total darkness; and the night period $(6 \mathrm{~h})$ received no illumination. Under this regime, daylight irradiance was above the saturating irradiance for C. nodosa from the collection site $(<70 \mu \mathrm{mol}$ quanta $\mathrm{m}^{-2} \mathrm{~s}^{-1}$, Olivé et al. 2013). Aquaria were randomly repositioned every $5 \mathrm{~d}$ (8x during the experiment) to eliminate any unknown effects related to spatial position within the light system.

To avoid accumulation of nutrients and metabolites, we performed a partial $(80 \%)$ seawater change on each aquarium every $4 \mathrm{~d}$ using natural seawater (UV sterilised, $10 \mu \mathrm{m}$ filtered) held in reservoirs maintained at the appropriate $\left[\mathrm{CO}_{2}\right]$ to avoid changes in the water chemistry during water replacement. Salinity, temperature (Mettler-Toledo InLab 737 IP67 temperature-conductivity combination electrode) and $\mathrm{pH}$ (NBS scale, Mettler-Toledo InLab Expert Pro temperature- $\mathrm{pH}$ combination electrode; calibrated prior to every use) were monitored in each aquarium every $2 \mathrm{~d}$ (23 time-point measurements) and were 
taken $6.5 \mathrm{~h}$ after the initiation of the dawn cycle. Seawater samples (20 ml, $0.45 \mu \mathrm{m}$ filtered) were taken 5 times during the experiment from the seawater reservoir and from 6 random aquaria per $\left[\mathrm{CO}_{2}\right]$ treatment the day after water exchange for monitoring water column nutrient concentrations $\left(\mathrm{NH}_{4}-\mathrm{N}, \mathrm{NO}_{\mathrm{x}}-\mathrm{N}\right.$ [= $\mathrm{NO}_{2}+\mathrm{NO}_{3}$ ] and $\mathrm{PO}_{4}-\mathrm{P}, \mathrm{mg} \mathrm{l}^{-1}$ ). Growth of epiphytes was minimal, but allowed throughout the experiment. The total experimental period was $42 \mathrm{~d}$.

\section{Plant measurements}

Prior to transplantation, each $C$. nodosa plant was blotted dry with paper towel and weighed (initial fresh weight; $\mathrm{FW}_{0}, \mathrm{~g}$ ). The number of leaves was counted per shoot (leaf abundance), and the length, width and thickness of all leaves were determined using a ruler $( \pm 0.1 \mathrm{~cm})$, a digital calliper $( \pm 0.01 \mathrm{~mm})$ and a thickness gauge $( \pm 0.01 \mathrm{~mm})$, respectively. Photosynthetic shoot size or shoot leaf area $\left(\mathrm{cm}^{2}\right.$ shoot $\left.^{-1}\right)$ was calculated as the sum of the 1-side area (leaf length $\times$ leaf width) of each leaf within a shoot. The youngest leaf in each shoot was hole punched $1 \mathrm{~cm}$ above the sheath to monitor leaf growth (Peralta et al. 2000), and each rhizome was tagged with a numbered tape for plant identification and to track the potential production of new shoots and internodes. To avoid underestimation of the leaf-breaking force, we did not pierce the whole shoot above the leaf sheath, because this could have resulted in leaves breaking in this area during the breaking test. Initially, plants had a mean $( \pm 1 \mathrm{SE}, \mathrm{n}=60)$ fresh biomass of $1.13 \pm 0.05 \mathrm{~g} \mathrm{FW}$ plant $^{-1}$, leaf abundance of $2.76 \pm$ 0.07 leaves shoot ${ }^{-1}$, total leaf area of $10.87 \pm 0.40 \mathrm{~cm}^{2}$ shoot $^{-1}$ and the following morphological characteristics: leaf length $=13.44 \pm 0.37 \mathrm{~cm}$, leaf thickness $=$ $0.23 \pm 0.01 \mathrm{~mm}$, leaf width $=2.98 \pm 0.04 \mathrm{~mm}$.

At the end of the experiment, each plant unit was harvested, cleaned of sediments and epiphytes, blotted dry with paper towel and immediately weighed for final fresh weight $\left(F_{\mathrm{f}}, \mathrm{g}\right)$ determination. The leaf abundance and leaf morphometry (length, width and thickness, averaged for all leaves in a shoot) of each plant were determined again, and the position of the initial marked leaf was recorded as a reference to separate new and old leaves.

Leaf growth in each shoot was estimated using 2 traits, following generally accepted standard methodology (Peralta et al. 2000, 2005). We estimated shoot elongation rate (SER, cm shoot ${ }^{-1} \mathrm{~d}^{-1}$, see Eq. 1 below) as the total increase of leaf length in a shoot per unit of time, computed from the length of the new leaves in the shoot and the increase in length of the old leaves. Leaf loss rate (LLR, cm leaf $\operatorname{shoot}^{-1} \mathrm{~d}^{-1}, \mathrm{Eq} .2$ ) was estimated as the total loss of leaf length in a shoot per unit of time, computed from the sum of the length of the initial leaves lost over the experimental period.

$$
\operatorname{SER}\left(\mathrm{cm} \mathrm{shoot}^{-1} \mathrm{~d}^{-1}\right)=\frac{\sum_{i=1}^{n}\left[\left(L_{i, \mathrm{f}}-L_{i, 0}\right)>0\right]}{t_{\mathrm{f}}-t_{0}}
$$

$\operatorname{LLR}\left(\mathrm{cm} \mathrm{shoot}^{-1} \mathrm{~d}^{-1}\right)=\frac{\sum_{i=1}^{n}\left[\left(L_{i, \mathrm{f}}-L_{i, 0}\right)<0\right]-\sum_{i=1}^{m} L_{i, 0}}{t_{\mathrm{f}}-t_{0}}$

where $L=$ leaf length $(\mathrm{cm})$, subscript $i$ refers to the $i^{\text {th }}$ leaf within the shoot, $n=$ the number of leaves at the end of the study period, $m=$ the number of leaves lost during the study period, subscript $f$ and 0 refer, respectively, to final and initial conditions, and $t_{\mathrm{f}}-t_{0}$ = experimental duration (d). In addition, we determined the plant biomass balance rate (PBR, mg FW shoot $^{-1} \mathrm{~d}^{-1}$ ), i.e. the gains/losses in biomass of the plant per unit of time, as the difference in epiphytecleaned fresh biomass of each plant unit (i.e. shoot, portion of rhizome and roots) between the day of transplantation into the aquaria and the harvest day (Eq. 3):

$$
\operatorname{PBR}\left(\mathrm{mg} \mathrm{FW} \mathrm{shoot}^{-1} \mathrm{~d}^{-1}\right)=\frac{\mathrm{FW}_{\mathrm{f}}-\mathrm{FW}_{0}}{t_{\mathrm{f}}-t_{0}}
$$

Leaf-breaking force at the end of the experiment was measured in a tensometer (Intron ${ }^{\circledR}$ model 5567 and BlueHill ${ }^{\circledR}$ software v. 2.18), using a 5 N-load cell and pneumatic action grips. To avoid effects of leaf age on the measurements (de los Santos et al. 2016b), the first outermost adult leaf (i.e. with a developed sheath) with a healthy appearance (green colouration) was selected from each shoot. Tensile tests were conducted within $48 \mathrm{~h}$ of plant harvesting, considered a valid time for measuring mechanical properties in seagrasses (de los Santos et al. 2016b). Leaves were individually clamped into the grips, and the ligule (the junction of the blade and the sheath) was positioned in the centre of the gauge (length $20 \mathrm{~mm}$ ). Load was set to $0 \mathrm{~N}$ at the start of each test and leaves were then stretched at a constant velocity of $10 \mathrm{~mm}$ $\mathrm{min}^{-1}$. Displacement $(\mathrm{mm})$ and force $(\mathrm{N})$ were recorded every $0.1 \mathrm{~s}$ until the point of leaf fracture, when the breaking force $(\mathrm{N})$ was recorded. Only tests in which the leaves broke at the ligule and did not slip whilst being pulled apart were included in our statistical analyses (90\% of tested leaves). After completion of the tensile tests, plants and epiphytes were dried separately at $60^{\circ} \mathrm{C}$ for $24 \mathrm{~h}$ to estimate plant dry biomass ( $g$ dry weight [DW] shoot ${ }^{-1}$ ) and epiphyte cover ( $\mathrm{g} \mathrm{DW} \mathrm{cm}^{-2}$ shoot $^{-1}$ ). 


\section{Statistical analysis}

Data are presented as means and associated SEs. Differences in seawater properties (temperature, salinity and nutrient concentration) among treatments were examined using a 1-way analysis of variance (ANOVA, fixed factor with 4 levels: the 3 $\left[\mathrm{CO}_{2}\right]$ projected scenarios plus the seawater reservoir). We used 2-way analysis of covariance for $\mathrm{pH}$ with the independent nominal variable $\left[\mathrm{CO}_{2}\right]$ projected scenarios (3 levels: 'present day', 'short-term projected' and 'long-term projected') and time as the covariate. Differences in $\mathrm{pH}$ between the procedural control (C. nodosa absent) and experimental aquaria (C. nodosa present) were examined using a 2 -way ANOVA with $\left[\mathrm{CO}_{2}\right]$ projected scenarios and the presence/absence of $C$. nodosa as independent nominal variables. We defined the time span for $\mathrm{pH}$ stabilisation in the system using the slope estimate from linear regression. The effect of atmospheric $\mathrm{CO}_{2}$ enrichment on leaf morphometry (length, thickness and width), plant dynamics (biomass balance, shoot elongation/loss rates), and leaf-breaking force were examined using a linear mixed effects regression model $\left[\mathrm{CO}_{2}\right]$ was included as a fixed factor $(3$ levels: 'present day', 'short-term projected' and 'longterm projected') and aquarium as a random factor, since some variation may exist amongst aquaria, and the focus of our study concerns the conditions they represent rather than the aquaria themselves. The model was fit by maximum likelihood, and Type III Wald $\chi^{2}$ tests were used to assess the significance of the fixed effect in the model. Pairwise comparisons to identify homogenous groups were identified using Tukey's multiple comparison tests. Visual inspection of residual plots did not reveal any obvious deviation from homoscedasticity or normality in the linear models. To test the hypothesis that leaf growth enhancement is associated with leaf strengthening (breaking force), we used Pearson's correlation coefficient and linear regression analy- sis. All statistical analysis was conducted in $\mathrm{R}(\mathrm{R}$ Development Core Team 2014) using the 'Ime4' library (Bates et al. 2015)

\section{RESULTS}

\section{Physico-chemical parameters in the water column}

The mean seawater temperature and salinity in the aquaria were $19.3 \pm 0.3^{\circ} \mathrm{C}$ and $34.8 \pm 0.6$ over the experimental period, without differences among treatments ( $\mathrm{p}>0.05$; data not shown). $\left[\mathrm{NH}_{4}-\mathrm{N}\right]$, $\left[\mathrm{NO}_{\mathrm{x}}-\mathrm{N}\right]$ and $\left[\mathrm{PO}_{4}-\mathrm{P}\right]$ in the seawater were high, and did not differ among $\left[\mathrm{CO}_{2}\right]$ treatments (Table 1). Nutrient concentration was lower in the experimental aquaria than in the seawater reservoir, with the exception of $\mathrm{NH}_{4}-\mathrm{N}$, indicating the occurrence of nutrient uptake by the plants and associated epiphytes (Table 1).

Seawater $\mathrm{pH}$ in the aquaria differed between $\left[\mathrm{CO}_{2}\right]$ scenarios (interaction: $\left[\mathrm{CO}_{2}\right] \times$ seagrass presence/absence, $F_{2,741}=4.77, \mathrm{p}=0.009$; Fig. 1a). Relative to present day conditions $(\mathrm{pH}=8.81 \pm 0.02), \mathrm{pH}$ was lower in the short-term projected $(\mathrm{pH}=8.37 \pm$ $0.01)$ and long-term projected $(\mathrm{pH}=8.13 \pm 0.01)$ treatments. In the absence of plants, $\mathrm{pH}$ was lower: $8.29 \pm 0.04$ (present day conditions), $8.04 \pm 0.03$ (short-term projected scenario) and $7.82 \pm 0.01$ (longterm projected scenario). An initial $10 \mathrm{~d}$ period was observed in which $\mathrm{pH}$ slightly increased over time (pH-time regression slopes significantly different from 0: present day $\left[\mathrm{CO}_{2}\right]$, slope $=0.066$; short-term projected $\left[\mathrm{CO}_{2}\right]$, slope $=0.030$; long-term projected $\left[\mathrm{CO}_{2}\right]$, slope $=0.018$ ). Following this period, $\mathrm{pH}$ stabilised and remained relatively constant within each $\left[\mathrm{CO}_{2}\right]$ for the rest of the experimental period (Fig. 1b; slopes insignificantly different from 0: present day $\left[\mathrm{CO}_{2}\right]$, slope $=0.006 \mathrm{pH}$; short-term projected $\left[\mathrm{CO}_{2}\right]$, slope $=-0.0001$; long-term projected $\left[\mathrm{CO}_{2}\right]$, slope $=$ $-0.001)$.

Table 1. Mean ( $\pm 1 \mathrm{SE}, \mathrm{n}$ in parentheses) seawater nutrient concentrations $\left(\mathrm{mg} \mathrm{l}^{-1}\right)$ in the seawater reservoir (day of renewal) and experimental aquaria (day after renewal) over the $6 \mathrm{wk}$ experimental period. $\left[\mathrm{CO}_{2}\right]$ treatments are present day (pH 8.29), short-term projected $(\mathrm{pH} 8.04)$ and long-term projected $\left(\mathrm{pH}\right.$ 7.82). Significance of $\left[\mathrm{CO}_{2}\right]$ treatments and reservoir (1-way ANOVA) and associated Tukey's multiple pairwise comparisons (superscript letter denotes groupings) are presented

\begin{tabular}{|c|c|c|c|c|c|c|}
\hline \multirow{2}{*}{ Nutrient } & \multirow{2}{*}{ Reservoir } & \multicolumn{3}{|c|}{$-\left[\mathrm{CO}_{2}\right]$ projected scenario } & \multicolumn{2}{|c|}{$\longrightarrow$ ANOVA } \\
\hline & & Present day & Short-term & Long-term & $F(\mathrm{df})$ & $\mathrm{p}$ \\
\hline $\mathrm{NH}_{4}{ }^{+}-\mathrm{N}$ & $0.09 \pm 0.01(3)$ & $0.16 \pm 0.03(20)$ & $0.12 \pm 0.02(19)$ & $0.13 \pm 0.02(19)$ & $1.819(3,50)$ & 0.1556 \\
\hline $\mathrm{NO}_{\mathrm{x}}{ }^{-}-\mathrm{N}$ & $4.19 \pm 0.31(7)^{\mathrm{a}}$ & $2.03 \pm 0.40(14)^{b}$ & $2.09 \pm 0.49(11)^{b}$ & $2.39 \pm 0.39(10)^{b}$ & $56.6(3,20)$ & $<0.001$ \\
\hline $\mathrm{PO}_{4}{ }^{3-}-\mathrm{P}$ & $0.62 \pm 0.02(7)^{\mathrm{a}}$ & $0.24 \pm 0.05(16)^{b}$ & $0.35 \pm 0.07(8)^{\mathrm{b}}$ & $0.24 \pm 0.06(13)^{\mathrm{b}}$ & $333.2(3,22)$ & $<0.001$ \\
\hline
\end{tabular}



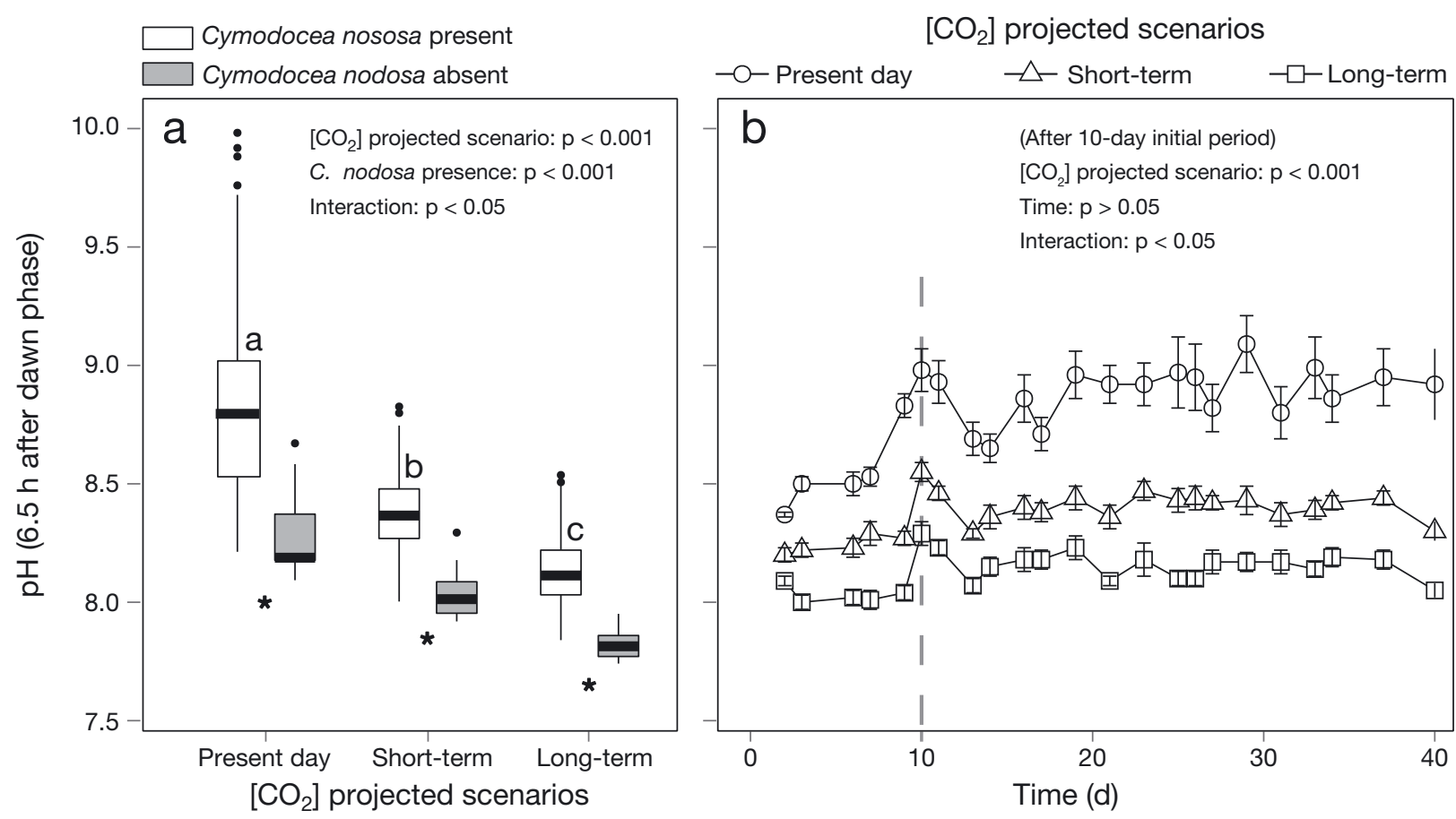

Fig. 1. Seawater pH for (a) aquaria with and without the seagrass Cymodocea nodosa, and (b) aquaria containing C. nodosa over the 6 wk experimental period (mean $\pm 1 \mathrm{SE}$ ). Statistical significance ( $p$-values) is given in panel (a) for the 2-way ANOVA ([CO $\left.{ }_{2}\right]$ projected scenario, presence/absence of $C$. nodosa and their interaction), and in panel (b) for the 2-way ANCOVA (time, [CO ${ }_{2}$ ] projected scenario and their interaction). In (a), superscript letters represent post hoc Tukey pairwise groupings that indicate differences among $\left[\mathrm{CO}_{2}\right]$ projected scenarios; asterisks denote differences between the procedural control (C. nodosa absent) and experimental aquaria (C. nodosa present). Dashed line in (b) marks the time of $\mathrm{pH}$ stabilisation in the system (10 d). Boxplot bar: median; box: interquartile range (IQR); whiskers: max./min. values within the $1.5 \times$ IQR of the hinge; dots: outliers

\section{Plant responses}

Cymodocea nodosa plants appeared healthy throughout the experiment: seagrass tissues did not exhibit any evidence of necrosis, leaves had a bright green colour (with the exception of senescent leaves, which were greyish), and rhizomes had a pinkish colour common for this species. Epiphytic cover was minimal $\left(0.002 \mathrm{~g} \mathrm{DW} \mathrm{cm}^{-2}\right.$ of leaf surface per shoot, $\mathrm{n}=24$ ) or absent. All plants survived in the short- and long-term projected $\left[\mathrm{CO}_{2}\right]$ treatments, but there was some negligible mortality ( 2 shoots) under present day $\left[\mathrm{CO}_{2}\right]$ conditions.

At the onset of the experiment, intense leaf shedding (release of the leaf blade, i.e. above the ligule) was observed, which involved the elimination of the long leaves that were present on the shoots from the field. Plants did not produce new shoots at any of the internodes over the experimental period, and new leaves developed only from the existing shoot. Indeed, $87.6 \pm 15.8 \%$ of leaves in a shoot at the end of the experiment were generated during the experimental period $(\mathrm{n}=58$ shoots). Newly produced replacement tissue had different dimensions. Whilst initial shoots had an average leaf abundance of 2.76 \pm 0.07 leaves shoot $^{-1}$ and average leaf length of 13.38 $\pm 0.36 \mathrm{~cm}$, at the end of the experiment, leaf abundance subtly increased, ranging from 2.9 to 3.3 leaves shoot ${ }^{-1}$ and leaf length substantially decreased, ranging from 9.16 to $9.53 \mathrm{~cm}$. The average shoot leaf area was initially $10.87 \mathrm{~cm}^{2}$ shoot $^{-1}$, but was reduced to $6.47-7.91 \mathrm{~cm}^{2}$ shoot $^{-1}$ in the final shoots.

Leaf morphometry did not differ among $\left[\mathrm{CO}_{2}\right]$ treatments (linear mixed effects model, $\mathrm{df}=2, \mathrm{p}>$ $0.05, \chi^{2}=0.41$ for length, $\chi^{2}=1.39$ for thickness, and $\chi^{2}=0.48$ for width, Table 2). Leaf abundance was significantly higher in plants grown under short-term projected $\left[\mathrm{CO}_{2}\right]\left(3.6 \pm 0.2\right.$ leaves shoot $\left.{ }^{-1}\right)$ than those grown under present day $\left[\mathrm{CO}_{2}\right](2.9 \pm 0.1$ leaves shoot $^{-1}$ ), and both were similar to plants grown under long-term projected $\left[\mathrm{CO}_{2}\right]\left(3.3 \pm 0.2\right.$ leaves shoot $\left.{ }^{-1}\right)$ (linear mixed effects model, $\chi^{2}=9.06, \mathrm{df}=2, \mathrm{p}=$ 0.011, Table 2). Biomass balance was positive in plants grown under short-term projected $\left[\mathrm{CO}_{2}\right](2.14$ $\pm 0.78 \mathrm{mg} \mathrm{FW}$ shoot ${ }^{-1} \mathrm{~d}^{-1}$ ) but negative in plants growing in present day $\left[\mathrm{CO}_{2}\right](-2.12 \pm 0.76 \mathrm{mg} \mathrm{FW}$ shoot $\left.^{-1} \mathrm{~d}^{-1}\right)$ and long-term projected $\left[\mathrm{CO}_{2}\right](-2.27 \pm$ $\left.1.34 \mathrm{mg} \mathrm{FW} \mathrm{shoot}^{-1} \mathrm{~d}^{-1}\right)\left(\chi^{2}=13.1, \mathrm{df}=2, \mathrm{p}=0.001\right.$ ， 
Table 2. Summary of the architectural, mechanical and dynamical traits of Cymodocea nodosa obtained at the end of the experiment (mean $\pm 1 \mathrm{SE}, \mathrm{n}=20$; except for the present day [380 ppm] treatment, where $\mathrm{n}=18$ because 2 shoots died). [CO ${ }_{2}$ ] treatments are present day ( $\mathrm{pH}$ 8.29), short-term projected ( $\mathrm{pH} 8.04)$ and long-term projected (pH 7.82). Summaries of the statistical findings (linear mixed effects model, $\left[\mathrm{CO}_{2}\right]$ as fixed factor and aquaria as random factor) are presented. Superscript letters represent post hoc Tukey pairwise groupings that indicate differences among $\left[\mathrm{CO}_{2}\right]$ treatments; asterisks indicate the level of statistical significance $\left({ }^{* * *} \mathrm{p}<0.001,{ }^{* *} \mathrm{p}<0.01,{ }^{*} \mathrm{p}<0.05\right)$; DW: dry weight, FW: fresh weight

\begin{tabular}{|c|c|c|c|c|c|}
\hline \multirow[t]{3}{*}{ Trait } & \multicolumn{3}{|c|}{$\left[\mathrm{CO}_{2}\right]$ projected scenario } & \multirow{2}{*}{\multicolumn{2}{|c|}{$\begin{array}{c}\text { Linear mixed effects } \\
\text { model }(\mathrm{df}=2)\end{array}$}} \\
\hline & \multirow[t]{2}{*}{ Present day } & \multirow[t]{2}{*}{ Short-term } & \multirow[t]{2}{*}{ Long-term } & & \\
\hline & & & & $\chi^{2}$ & $\mathrm{p}$ \\
\hline Leaf abundance (leaves shoot ${ }^{-1}$ ) & $2.89 \pm 0.14^{\mathrm{a}}$ & $3.60 \pm 0.20^{\mathrm{b}}$ & $3.30 \pm 0.16^{\mathrm{ab}}$ & 9.06 & $0.011^{* *}$ \\
\hline Mean leaf length (cm) & $9.63 \pm 0.47$ & $9.53 \pm 0.28$ & $9.16 \pm 0.47$ & 0.41 & 0.816 \\
\hline Mean leaf thickness (mm) & $0.20 \pm 0.01$ & $0.21 \pm 0.01$ & $0.20 \pm 0.01$ & 1.39 & 0.499 \\
\hline Mean leaf width (mm) & $2.27 \pm 0.06$ & $2.28 \pm 0.04$ & $2.24 \pm 0.05$ & 0.48 & 0.788 \\
\hline Shoot leaf area $\left(\mathrm{cm}^{2}\right.$ shoot $\left.^{-1}\right)$ & $6.47 \pm 0.67$ & $7.91 \pm 0.61$ & $6.57 \pm 0.54$ & 3.75 & 0.153 \\
\hline Plant dry biomass (g DW shoot ${ }^{-1}$ ) & $0.15 \pm 0.01^{\mathrm{a}}$ & $0.20 \pm 0.02^{\mathrm{b}}$ & $0.14 \pm 0.02^{\mathrm{a}}$ & 10.21 & $0.006^{* * *}$ \\
\hline Leaf-breaking force at ligule (N) & $1.72 \pm 0.13^{\mathrm{a}}$ & $2.30 \pm 0.18^{b}$ & $2.00 \pm 0.18^{\mathrm{ab}}$ & 6.75 & $0.034^{*}$ \\
\hline Plant biomass balance rate (mg FW shoot $\left.{ }^{-1} \mathrm{~d}^{-1}\right)$ & $-2.12 \pm 0.76^{\mathrm{a}}$ & $2.14 \pm 0.78^{\mathrm{b}}$ & $-2.27 \pm 1.34^{\mathrm{a}}$ & 13.1 & $0.001^{* *}$ \\
\hline Shoot elongation rate $\left(\mathrm{cm}\right.$ shoot $\left.^{-1} \mathrm{~d}^{-1}\right)$ & $0.60 \pm 0.05$ & $0.71 \pm 0.04$ & $0.64 \pm 0.05$ & 2.94 & 0.230 \\
\hline Leaf loss rate $\left(\mathrm{cm} \mathrm{shoot}^{-1} \mathrm{~d}^{-1}\right)$ & $0.80 \pm 0.04$ & $0.70 \pm 0.03$ & $0.83 \pm 0.04$ & 5.40 & 0.067 \\
\hline
\end{tabular}

Fig. 2a, Table 2). Shoot elongation rate did not differ among $\left[\mathrm{CO}_{2}\right]$ treatments (linear mixed effects model, $\chi^{2}=2.94, \mathrm{df}=2, \mathrm{p}=0.230$, Fig. $2 \mathrm{~b}$ ) and neither did the leaf loss rate $\left(\chi^{2}=5.40\right.$, df $=2, p=0.067$, Fig. 2 c). In contrast, leaves of plants growing under short-term projected $\left[\mathrm{CO}_{2}\right]$ supported higher tensile forces (2.30 $\pm 0.18 \mathrm{~N}$ ) than those growing under present day $\left[\mathrm{CO}_{2}\right](1.72 \pm 0.13 \mathrm{~N})$, whilst the leaf-breaking force of plants grown under long-term projected $\left[\mathrm{CO}_{2}\right]$ $(2.00 \pm 0.18 \mathrm{~N})$ formed an intermediate grouping (lin-
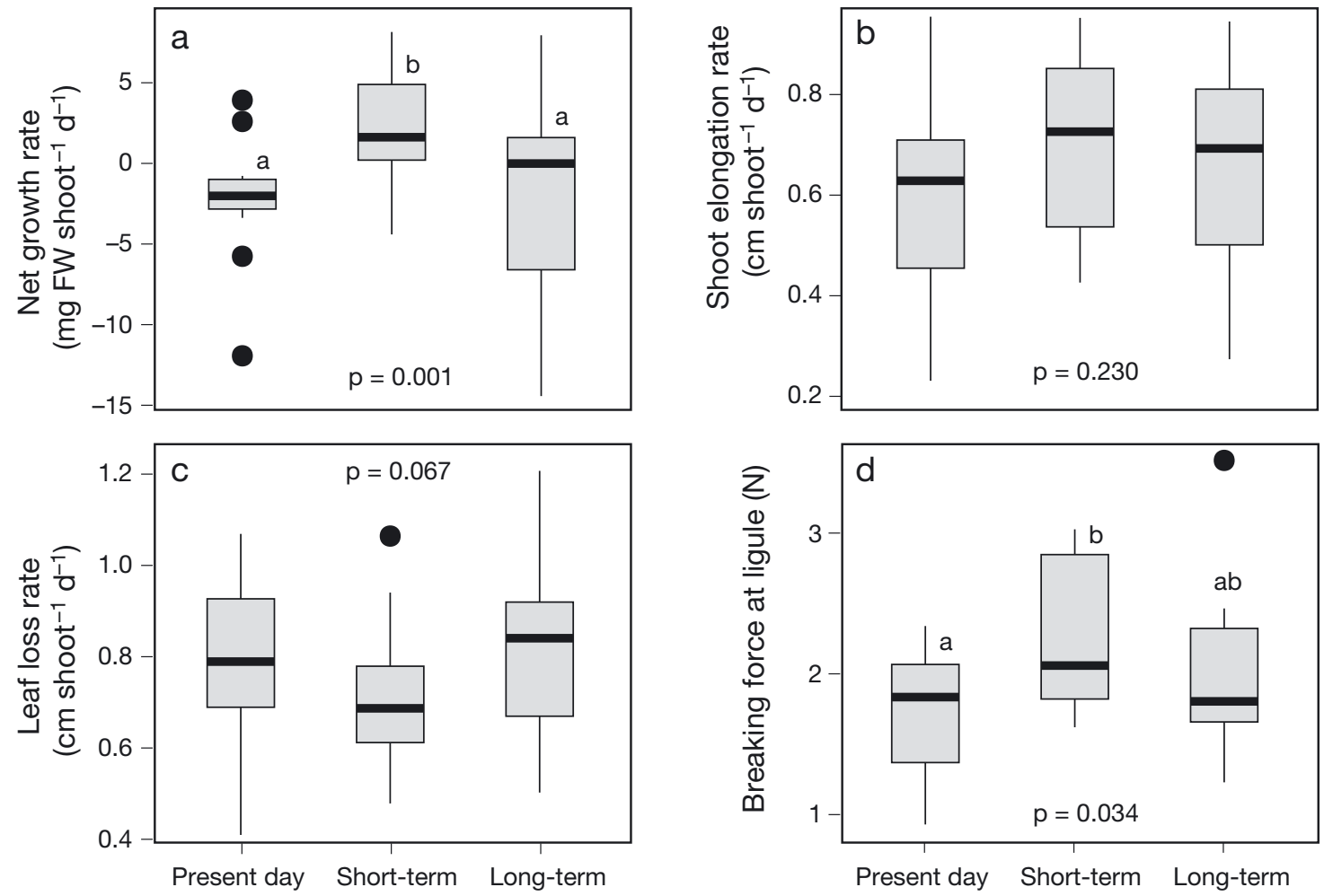

$\left[\mathrm{CO}_{2}\right]$ projected scenarios

Fig. 2. Response of the seagrass Cymodocea nodosa to $\left[\mathrm{CO}_{2}\right]$ scenarios (present day versus anticipated short-term and longterm $\left[\mathrm{CO}_{2}\right]$ projections). Statistical significance ( $\mathrm{p}$ values) of the $\left[\mathrm{CO}_{2}\right]$ scenario in the mixed-effects linear models is shown, and superscript letters represent post hoc Tukey pairwise groupings for $\left[\mathrm{CO}_{2}\right]$. FW: fresh weight 
ear mixed effects model, $\chi^{2}=6.75, \mathrm{df}=2, \mathrm{p}=0.034$; Fig. 2d). Plants with high elongation rates presented stronger leaves than plants with a low elongation rate, as given by the positive correlation of shoot elongation rate and breaking force (Fig. 3).

\section{DISCUSSION}

We have demonstrated that increasing atmospheric $\left[\mathrm{CO}_{2}\right]$ concentration affects the plant biomass balance rate and the leaf-breaking force of the temperate seagrass species Cymodocea nodosa and that the mechanical response is correlated with leaf growth. However, our data also indicate that other leaf traits (leaf morphology and leaf dynamics) that reflect different aspects of growth did not respond in the same way. This suggests that responses to increasing $\left[\mathrm{CO}_{2}\right]$ may manifest to a greater extent in the belowground tissues (e.g. Koch et al. 2013) or at the cellular level, since plant growth and development depend largely on the biosynthesis and remodelling of the cell wall (e.g. Sharma et al. 2014). This distinction is important, as it indicates that the evaluation of the effects of ocean acidification on processes that encompass multiple facets of response has the potential to be misleading when conclusions are based on a single,

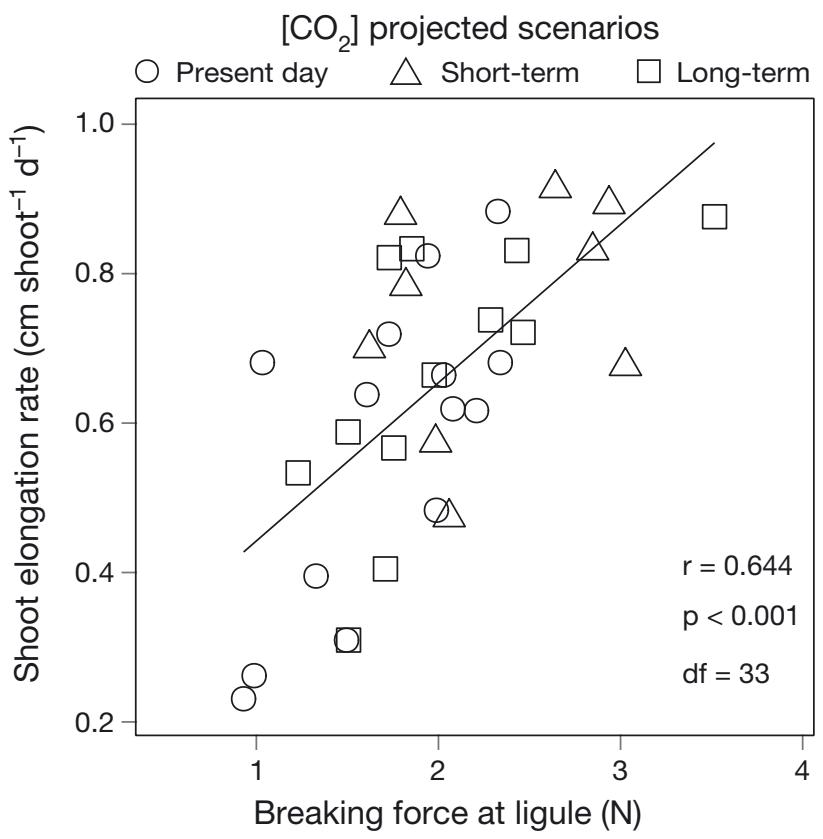

Fig. 3. Correlation between shoot elongation rate and breaking force for the seagrass Cymodocea nodosa indicates that breaking force is, at least partly, positively affected by higher rates of shoot elongation. Pearson's correlation coefficient $(r)$ is shown with its significance ( $p$ value) and degrees of freedom $(\mathrm{df})(\mathrm{n}=35)$ or a limited set of, response descriptors that are assumed to be representative.

Effects of ocean acidification on the growth of seagrasses have been reported for many species over short- and long-term scales (Table 3). Over the short term, we found no effect on shoot elongation rate, which is consistent with previous short-term studies for the same species (Tomas et al. 2015) and for the congeneric C. serrulata (Ow et al. 2015), as well as for other seagrass species exposed to longer experimental periods (Alexandre et al. 2012, Campbell \& Fourqurean 2013). The lack of effect in those traits might be explained by the short-term duration of the experiment. We found, however, that $C$. nodosa plants increased in biomass when growing under short-term projected $\left[\mathrm{CO}_{2}\right]$ conditions, but decreased under present day or long-term projected $\left[\mathrm{CO}_{2}\right]$ scenarios. The observed leaf shedding and production of new altered tissue (leaves with reduced leaf area) ultimately contributed to a negative biomass balance in plants from those 2 treatments, i.e. they lost more leaf tissue than they produced. The positive balance in plants growing under short-term projected $\left[\mathrm{CO}_{2}\right]$ conditions could be potentially explained by one or a combination of the following: (1) larger leaves, (2) higher leaf abundance, (3) denser tissues, (4) growth of belowground tissues. We can disregard 'larger leaves' because we did not observe differences in leaf morphometry among treatments. We can consider 'more leaves' as an explanation because the plants under $\mathrm{CO}_{2}$-enriched conditions showed a significantly higher leaf abundance, but this does not explain the difference in biomass balance between our $2 \mathrm{CO}_{2}$-enriched treatments. The 'denser tissues' and/or 'growth of belowground tissues' were not directly quantified but, based on the observed differences in plant dry biomass (i.e. dry weight of the whole shoot, including both below- and aboveground tissues, Table 2), they form a valid possibility. We observed that plants under the short-term projected $\left[\mathrm{CO}_{2}\right]$ scenario were significantly heavier $(0.20$ $\pm 0.02 \mathrm{~g} \mathrm{DW} \mathrm{shoot}^{-1}$ ) than plants from the other $2 \mathrm{sce}-$ narios $\left(0.15 \pm 0.01\right.$ and $0.14 \pm 0.02 \mathrm{~g} \mathrm{DW}$ shoot $\left.^{-1}\right)$. Hence, we explain the differences in the biomass balance by the higher abundance of leaves and heavier shoots in the short-term $\left[\mathrm{CO}_{2}\right]$ scenario. Increased biomass in the belowground tissues has been previously observed in C. serrulata (Russell et al. 2013) and Zostera marina when exposed to naturally high $\left[\mathrm{CO}_{2}\right]$ (Palacios \& Zimmerman 2007). The biomass decline due to leaf shedding is a commonly observed phenomenon in manipulative experiments that involve seagrasses (e.g. de los Santos et al. 2010, Col- 
lier et al. 2012), including C. nodosa (Malta et al. 2006). However, given the absence of measurements of biochemical and physiological responses in our experiment, we cannot distinguish the mechanistic basis of this observation.

It is important to recognise that the loss of biomass over the experimental period could also reflect inappropriate environmental conditions for $C$. nodosa. In general, however, the experimental set-up appeared favourable for the growth of this species, given (1) the high survival at the end of the experiment, (2) the fact that plants produced new leaves in all of the treatments, including those showing a decrease in biomass and (3) the observed $\mathrm{pH}$ increase in the aquaria containing plants relative to the controls, indicative of high productivity (Invers et al. 1997, Buapet et al. 2013). Accepting these observations, the negative plant biomass balance we observed might be explained by a shortage in resources. In particular, dissolved inorganic carbon concentrations are limiting under present day $\left[\mathrm{CO}_{2}\right]$ because they do not saturate the photosynthetic activity of seagrasses (reviewed by Koch et al. 2013), including C. nodosa (Invers et al. 2001). Under higher $\left[\mathrm{CO}_{2}\right]$, sub-optimal growth rates have been previously reported and justified by a shortcut in the availability of inorganic nutrients (Z. noltei, Alexandre et al. 2012). However, our plants were exposed to ambient high nutrient concentrations, so we discard this hypothesis. Although unlikely, plants could have been light-limited during the experiment despite the irradiance regime set in the mesocosms, which can be considered saturating for C. nodosa. These sub-optimal growth conditions appear to be absent at intermediate $\left[\mathrm{CO}_{2}\right]$, as plants increased their biomass and exhibited an increase in leaf abundance. Taken together, these observations suggest that the decreased $\mathrm{pH}$ associated with the elevated $\left[\mathrm{CO}_{2}\right]$ is somehow favourable for $C$. nodosa, most likely through enhancement of photosynthetic activity (Invers et al. 2001) that could, in turn, translate into elevated levels of carbon fixation and, consequently, more resources to support plant growth.

Mechanical traits are important in determining how plants resist abiotic and biotic physical forces (Read \& Stokes 2006), so an alteration of the biomechanics of seagrass leaves may have important ecological implications over extended periods of time. Here, we found that C. nodosa leaves may become slightly more tolerant of physical forces when growing in a moderately $\mathrm{CO}_{2}$-enriched medium. Hence, changes in its leaf mechanical properties might offset, either wholly or in part, the loss of habitat and 
persistence under various environmental futures, such as novel hydrodynamical forces associated with moderate levels of climate change (Young et al. 2011), or high nutrient regimes (La Nafie et al. 2012). On the other hand, the strengthening of leaf abscission could make it difficult for leaf shedding, leading to negative consequences such as overgrowth of epiphytes and resource demand by non-functional leaves. Variation in the breaking force of leaves is determined by morphological adjustments in the leaf cross-section area, changes in the material strength or both (Niklas 1992). Since we did not find any adjustment in the morphological attributes of C. nodosa leaves, we conclude that the observed changes in the leaf-breaking force are due to differences in the material strength of the tissues, in agreement with previous studies for intra-specific variation in breaking force of seagrass leaves (de los Santos et al. 2016a). Breaking force of seagrass leaves is often associated with structural reinforcement of the leaves, such as the proportion of fibre content (de los Santos et al. 2016a). We contend here that the higher leaf-breaking force of seagrass C. nodosa in a short-term projected $\left[\mathrm{CO}_{2}\right]$ scenario is most likely to be associated with a greater allocation of resources (structural carbohydrates) to the supporting tissues of the leaves. Accordingly, Kopp (1999) found a correlation between breaking force and leaf growth of seagrasses, such that seagrass leaves withstand higher forces during the active growing season than they do during lower periods of growth in winter. Clearly, insights from longer exposures, or from seagrass communities growing within the plumes of $\mathrm{CO}_{2}$ vents (e.g. HallSpencer et al. 2008) will be insightful, particularly with respect to determining the full extent and mechanistic basis for any response and to determine the generality, or otherwise, of our findings.

Biomechanical acclimation of $C$. nodosa leaves to $\mathrm{CO}_{2}$ enrichment is also likely to affect leaf palatability, as leaf fracture properties are intimately associated with the fibre content and $C: N$ ratio in seagrasses (de los Santos et al. 2012). For instance, Tomas et al. (2015) hypothesised that the alteration of structural traits of $C$. nodosa in an enriched $\mathrm{CO}_{2}$ medium could influence the feeding patterns of some herbivores. Biomechanical acclimation to $\mathrm{CO}_{2}$ needs to be investigated in concert with other traits involved in the leaf palatability, especially because other studies report that elevated $\mathrm{CO}_{2}$ leads to losses in protective phenolic compounds that commonly act as protection against grazing (Arnold et al. 2012) and a reduction in epiphytic infestation (Martin et al. 2008).
Our study emphasises the need to account for the interdependencies between environmental conditions and variations in multiple aspects of the structure and functioning of seagrass communities when considering the likely consequences of climate change. Elucidating the relative importance of the multitude of seagrass responses to ocean acidification, and the form of the interplay between them, will be challenging because ecological responses may be species-specific (Koch et al. 2013, Ow et al. 2015), mechanical traits are context dependent (interaction with multiple stressors, La Nafie et al. 2012, 2013; seasonal and developmental timing, de los Santos et al. 2012, 2016b), and both of these are complicated further by acclimation/adaptive capacity (Stillman \& Paganini 2015).

Acknowledgements. C.B.S. was supported, at the time of the experiment performance, by the Mobility Fellowships Programme of the EuroMarine Consortium (European Commission Seventh Framework Programme, FP7-ENV-2010.2.2.1-3), and presently by the Foundation of Science and Technology of Portugal (SFRH/BPD/119344/2016 and PTDC/MAR-EST/ 3223/2014). Additional support was received from the Natural Environment Research Council (NERC) through the UK Ocean Acidification Research Programme (UKOARP, grant reference NE/H017445/1, awarded to M.S. and J.A.G.). We thank G. Taylor and H. K. Smith (School of Biological Sciences, University of Southampton) for use of the Instron testing machine, M. Ribas-Ribas (Carl von Ossietzky Universität Oldenburg, Germany), C. Sturdy, A. Currie, R. Hale and M. Stinchcombe (Ocean and Earth Science, University of Southampton) for technical assistance and support. We appreciate the constructive criticism given by the anonymous reviewers

\section{LITERATURE CITED}

Alexandre A, Silva J, Buapet P, Björk M, Santos R (2012) Effects of $\mathrm{CO}_{2}$ enrichment on photosynthesis, growth, and nitrogen metabolism of the seagrass Zostera noltii. Ecol Evol 2:2625-2635

Arnold T, Mealey C, Leahey H, Miller AW, Hall-Spencer JM, Milazzo M, Maers K (2012) Ocean acidification and the loss of phenolic substances in marine plants. PLOS ONE 7:e35107

Bates D, Maechler M, Bolker B, Walker S (2015) Fitting linear mixed-effects models using lme4. J Stat Softw 67:1-48

* Buapet P, Gullström M, Björk M (2013) Photosynthetic activity of seagrasses and macroalgae in temperate shallow waters can alter seawater $\mathrm{pH}$ and total inorganic carbon content at the scale of a coastal embayment. Mar Freshw Res 64:1040-1048

Campbell JE, Fourqurean JW (2013) Effects of in situ $\mathrm{CO}_{2}$ enrichment on the structural and chemical characteristics of the seagrass Thalassia testudinum. Mar Biol 160: 1465-1475

Collier CJ, Waycott M, Ospina AG (2012) Responses of four Indo-West Pacific seagrass species to shading. Mar Pollut Bull 65:342-354 
de los Santos CB, Brun FG, Bouma TJ, Vergara JJ, PérezLloréns JL (2010) Acclimation of seagrass Zostera noltii to co-occurring hydrodynamic and light stresses. Mar Ecol Prog Ser 398:127-135

de los Santos CB, Brun FG, Onoda Y, Cambridge ML, Bouma TJ, Vergara JJ, Pérez-Lloréns JL (2012) Leaf-fracture properties correlated with nutritional traits in nine Australian seagrass species: implications for susceptibility to herbivory. Mar Ecol Prog Ser 458:89-102

de los Santos CB, Brun FG, Vergara JJ, Pérez-Lloréns JL (2013) New aspect in seagrass acclimation: Leaf mechanical properties vary spatially and seasonally in the temperate species Cymodocea nodosa Ucria (Ascherson). Mar Biol 160:1083-1093

* de los Santos CB, Onoda Y, Vergara JJ, Pérez-Lloréns JL and others (2016a) A comprehensive analysis of mechanical and morphological traits in temperate and tropical seagrass species. Mar Ecol Prog Ser 551:81-94

de los Santos CB, Vicencio-Rammsy B, Lepoint G, Remy F, Bouma TJ, Gobert S (2016b) Ontogenic variation and effect of collection procedure on leaf biomechanical properties of Mediterranean seagrass Posidonia oceanica (L.) Delile. Mar Ecol 37:750-759

* Duarte CM (1991) Allometric scaling of seagrass form and productivity. Mar Ecol Prog Ser 77:289-300

Fabry VJ, Seibel BA, Feely RA, Orr JC (2008) Impacts of ocean acidification on marine fauna and ecosystem processes. ICES J Mar Sci 65:414-432

Form A, Riebesell U (2012) Acclimation to ocean acidification during long-term $\mathrm{CO}_{2}$ exposure in the cold-water coral Lophelia pertusa. Glob Change Biol 18:843-853

Garrard S, Gambi MC, Scipione MB, Patti FP and others (2014) Indirect effects may buffer negative responses of seagrass invertebrate communities to ocean acidification. J Exp Mar Biol Ecol 461:31-38

Godbold JA, Solan M (2013) Long-term effects of warming and ocean acidification are modified by seasonal variation in species responses and environmental conditions. Phil Trans R Soc Lond B Biol Sci 368:20130186

Hall-Spencer JM, Rodolfo-Metalpa R, Martin S, Ransome E, Fine M, Turner SM, Buia MC (2008) Volcanic carbon dioxide vents show ecosystem effects of ocean acidification. Nature 454:96-99

Hendriks IE, Olsen YS, Ramajo L, Basso L and others (2014) Photosynthetic activity buffers ocean acidification in seagrass meadows. Biogeosciences 11:333-346

* Invers O, Romero J, Pérez M (1997) Effects of pH on seagrass photosynthesis: a laboratory and field assessment. Aquat Bot 59:185-194

* Invers O, Zimmerman RC, Alberte RS, Pérez M, Romero J (2001) Inorganic carbon sources for seagrass photosynthesis: an experimental evaluation of bicarbonate use in species inhabiting temperate waters. J Exp Mar Biol Ecol 265:203-217

Jiang ZJ, Huang XP, Zhang JP (2010) Effects of $\mathrm{CO}_{2}$ enrichment on photosynthesis, growth, and biochemical composition of seagrass Thalassia hemprichii (Ehrenb.) Aschers. J Integr Plant Biol 52:904-913

Koch M, Bowes G, Ross C, Zhang XH (2013) Climate change and ocean acidification effects on seagrasses and marine macroalgae. Glob Change Biol 19:103-132

Kopp BS (1999) Effects of nitrate fertilization and shading on physiological and biomechanical properties of eelgrass (Zostera marina L.). PhD dissertation, University of Rhode Island, Kingston, RI
Kroeker KJ, Kordas RL, Crim RN, Singh GG (2010) Metaanalysis reveals negative yet variable effects of ocean acidification on marine organisms. Ecol Lett 13: 1419-1434

Kroeker KJ, Kordas RL, Crim R, Hendriks IE and others (2013) Impacts of ocean acidification on marine organisms: quantifying sensitivities and interaction with warming. Glob Change Biol 19:1884-1896

*La Nafie YA, de los Santos CB, Brun FG, van Katwijk MM, Bouma TJ (2012) Waves and high nutrient loads jointly decrease survival and separately affect morphological and biomechanical properties in the seagrass Zostera noltii. Limnol Oceanogr 57:1664-1672

Ka Nafie YA, de los Santos CB, Brun FG, Mashoreng S, van Katwijk MM, Bouma TJ (2013) Biomechanical response of two fast-growing tropical seagrass species subjected to in situ shading and sediment fertilization. J Exp Mar Biol Ecol 446:186-193

Malta EJ, Brun FG, Vergara JJ, Hernández I, Pérez-Lloréns JL (2006) Recovery of Cymodocea nodosa (Ucria) Ascherson photosynthesis after a four-month dark period. Sci Mar 70:413-422

Martin S, Rodolfo-Metalpa R, Ransome E, Rowley S, Buia MC, Gattuso JP, Hall-Spencer J (2008) Effects of naturally acidified seawater on seagrass calcareous epibionts. Biol Lett 4:689-692

*Morris EP, Peralta G, Benavente J, Freitas R and others (2009) Caulerpa prolifera stable isotope ratios reveal anthropogenic nutrients within a tidal lagoon. Mar Ecol Prog Ser 390:117-128

Newcomb LA, Milazzo M, Hall-Spencer JM, Carrington E (2015) Ocean acidification bends the mermaid's wineglass. Biol Lett 11:20141075

Niklas KJ (1992) Plant biomechanics: an engineering approach to plant form and function. University of Chicago Press, Chicago, IL

* Olivé I, Vergara JJ, Pérez-Lloréns JL (2013) Photosynthetic and morphological photoacclimation of the seagrass Cymodocea nodosa to season, depth and leaf position. Mar Biol 160:285-297

* Ow YX, Collier CJ, Uthicke S (2015) Responses of three tropical seagrass species to $\mathrm{CO}_{2}$ enrichment. Mar Biol 162:1005-1017

Pagès JF, Pérez M, Romero J (2010) Sensitivity of the seagrass Cymodocea nodosa to hypersaline conditions: a microcosm approach. J Exp Mar Biol Ecol 386:34-38

Palacios SL, Zimmerman RC (2007) Response of eelgrass Zostera marina to $\mathrm{CO}_{2}$ enrichment: possible impacts of climate change and potential for remediation of coastal habitats. Mar Ecol Prog Ser 344:1-13

* Peralta G, Pérez-Lloréns JL, Hernández I, Brun FG and others (2000) Morphological and physiological differences between two morphotypes of Zostera noltii Hornem. from the south-western Iberian Peninsula. Helgol Mar Res 54:80-86

* Peralta G, Brun FG, Hernández I, Vergara JJ, Pérez-Lloréns JL (2005) Morphometric variations as acclimation mechanisms in Zostera noltii beds. Estuar Coast Shelf Sci 64: 347-356

* Pérez M, Romero J, Duarte CM, Sand-Jensen K (1991) Phosphorus limitation of Cymodocea nodosa growth. Mar Biol 109:129-133

R Development Core Team (2014) R: a language and environment for statistical computing. R Foundation for Statistical Computing, Vienna 
Ragazzola F, Foster LC, Form A, Anderson PS, Hansteen TH, Fietzke J (2012) Ocean acidification weakens the structural integrity of coralline algae. Glob Change Biol 18:2804-2812

Read J, Stokes A (2006) Plant biomechanics in an ecological context. Am J Bot 93:1546-1565

Riebesell U, Fabry VJ, Hansson L, Gattuso JP (2010) Guide to best practices for ocean acidification research and data reporting. Publications Office of the European Union, Luxembourg

Russell BD, Connell SD, Uthicke S, Muehllehner N, Fabricius KE, Hall-Spencer JM (2013) Future seagrass beds: Can increased productivity lead to increased carbon storage? Mar Pollut Bull 73:463-469

Sharma N, Sinha PG, Bhatnagar AK (2014) Effect of elevated $\left[\mathrm{CO}_{2}\right]$ on cell structure and function in seed plants. Clim Chang Environ Sustain 2:69-104

Stillman JH, Paganini AW (2015) Biochemical adaptation to ocean acidification. J Exp Biol 218:1946-1955

Stocker TF, Qin D, Plattner GK, Tignor M and others (eds) (2013) Climate change 2013: the physical science basis. Contribution of Working Group I to the Fifth Assessment Report of the Intergovernmental Panel on Climate

Editorial responsibility: William Kemp,

Cambridge, Maryland, USA
Change. Cambridge University Press, Cambridge

* Thom RM (1996) $\mathrm{CO}_{2}$-enrichment effects on eelgrass (Zostera marina L.) and bull kelp (Nereocystis luetkeana (Mert.) P \& R.). Water Air Soil Pollut 88: 383-391

Tomas F, Martínez Crego B, Hernán G, Santos R (2015) Responses of seagrass to anthropogenic and natural disturbances do not equally translate to its consumers. Glob Change Biol 21:4021-4030

* Unsworth RKF, Collier CJ, Henderson GM, McKenzie LJ (2012) Tropical seagrass meadows modify seawater carbon chemistry implications for coral reefs impacted by ocean acidification. Environ Res Lett 7:024026

* Vergara JJ, García-Sánchez MP, Olivé I, García-Marín P, Brun FG, Pérez-Lloréns JL, Hernández I (2012) Seasonal functioning and dynamics of Caulerpa prolifera meadows in shallow areas: an integrated approach in Cadiz Bay Natural Park. Estuar Coast Shelf Sci 112:255-264

Vergés A, Becerro MA, Alcoverro T, Romero J (2007) Variation in multiple traits of vegetative and reproductive seagrass tissues influences plant-herbivore interactions. Oecologia 151:675-686

* Young IR, Zieger S, Babanin AV (2011) Global trends in wind speed and wave height. Science 332:451-455

Submitted: April 28, 2016; Accepted: April 12, 2017

Proofs received from author(s): May 22, 2017 